\title{
Comparative assessment of Rhododendron (Rhododendron arboreum Sm.) flowers extract beverages through biochemical analysis and its quality evaluation during storage
}

\author{
N.S. Thakur, Aarti, Sunakshi Gautam», Aashu Chandel, Neerja Rana, Abhimanyu Thakur and Hamid \\ Department of Food Science and Technology, Dr. YS Parmar University of Horticulture and Forestry, Nauni, Solan-173230, Himachal Pradesh, India
}

\section{Article Info}

Article history

Received 6 October 2020

Revised 23 November 2020

Accepted 25 November 2020

Published online 30 December 2020

Keywords

Rhododendron flower extract

Syrup

Total phenols

Anthocyanins

Sensory parameters

Storage quality

\begin{abstract}
Besides being a refreshing drink, the rhododendron has numerous healthful, nutritive and aromatic properties. The limited availability of flowers in the market, makes it an important value-added crop. So, the present study was undertaken for the development of syrup, its storage and quality evaluation in ambient and refrigerated conditions. Different combinations of flower extract $(25,30,35$ and $40 \%)$ and sugar solution $\left(65\right.$ and $\left.70^{\circ} \mathrm{B}\right)$ were used for attaining most suitable amalgamation of syrup. Out of all, syrup prepared with 35 per cent extract, $65^{\circ} \mathrm{B}$ TSS and 1.50 per cent acidity was packed in bottles and stored for six months under ambient and refrigerated temperature conditions. There was not much change in quality attributes for a period of six months under both conditions. As storage period proceeds, various physicochemical characteristics increased like TSS (65 to $65.65^{\circ} \mathrm{B}$ ), reducing sugars (48.31 to $51.35 \%$ ) and total sugars (63.15 to $64.79 \%)$. Whereas, decreasing trend was observed in red TCU (19.21 to 14.05$)$, yellow TCU (2.05 to 1.38$)$, titratable acidity (1.50 to $1.35 \%$ ), ascorbic acid (8.12 to $3.81 \mathrm{mg} / 100 \mathrm{ml}$ ), anthocyanins $(26.54$ to $20.40 \mathrm{mg} / 100 \mathrm{ml})$, total phenols (35.55 to $30.42 \mathrm{mg} / 100$ $\mathrm{ml}$ ) and antioxidant activity (25.90 to $21.54 \%)$. The results showed slower changes in refrigerated storage as compared to ambient. Although, the changes were minimum in beverage packed in glass bottle. Also, both the packaging material (glass bottle and PET bottle) were found suitable for the safe storage of product for six months.
\end{abstract}

\section{Introduction}

The word rhododendron is derived from Greek language in which "Rhodo" means "rose" and "Dendron" means "tree" (Kumar et al., 2019). It belongs to the family Ericaceae and was first described by Carl Linnaeus in year 1837 (Tiwari and Chauhan, 2006). The family comprises of about 80 species (with 10 subspecies and 14 varieties) in different altitudes (1500 to $5500 \mathrm{~m}$ above mean sea level) and regions in the Himalaya (Devi and Vats, 2017). The shrub is national flower of Nepal, where its vernacular name is "Laligurans" and is state tree of Uttrakhand. The other regional names are 'Burans, Bras, Buras or Barahke-phool' (Srivastava, 2012; Kashyap et al., 2017). Temperate region of Northern hemisphere has been found as suitable for its growth are China, Japan, Myanmar, Thailand, Malaysia, Indonesia, Philippines, New Guinea, Afghanistan, Pakistan, India, Nepal, Southern Europe and Northern America

Corresponding author: Ms. Sunakshi Gautam Department of Food Science and Technology, Dr. Yashwant Singh Parmar University of Horticulture and Forestry, Nauni, Solan-173230, Himachal Pradesh, India

E-mail: sunakshigautam7@gmail.com

Tel.: +91-9805588330
(Heywood et al., 2007). In India it is mainly found in the states like Arunachal Pradesh, Himachal Pradesh, Jammu and Kashmir, Manipur, Nagaland, Sikkim and Uttrakhand (Katoch, 2014).

Out of all species available, the most important and stately known is Rhododendron arboreum $\mathrm{Sm}$. The flowers are of various colours, ranged from a deep scarlet to red with white markings and pink to white also. Bright red colour is more prominent in lower elevations (Orwa et al., 2009) with sweetish sour taste (Purohit, 2014). The flowers are excellent in exhibiting nutritional, medicinal and aromatic properties (Devi et al., 2018). They are found to be rich source of carbohydrates, amino acids, sugars, pectin, anthocyanins and vitamin C (Solanki et al., 2013; Thakur et al., 2020). More specifically, they contain phenols, saponins, xanthoproteins, steroids, tannins and coumarin compounds (Gautam et al., 2016). The flower showed $\alpha$-glucosidase inhibitor and potent diabetic activity (Krishna et al., 2012). There are very less literature available on rhododendron flower extract and its utilization as value added product. So, keeping in view its availability and importance with respect to its quality characteristics, the present study was undertaken to develop beverage from flower and its quality evaluation during storage. 


\section{Materials and Methods}

\subsection{Raw material and extraction of extract}

The research was conducted at the laboratory of Department of Food Science and Technology, UHF, Nauni, Solan (HP). Fresh flowers of Rhododendron arboretum Sm. procured from district Sirmour, Himachal Pradesh. The fruit identification and authentication was carried out by Department of Forest Products, Dr YSPUHF, Nauni, Solan, India vide-UHF herbarium number13915 , YSPUHF, Solan, India. The fruits were further used for the estimation of various physicochemical characteristics and preparation of flower extract. The extract was prepared by using flower petals and cooked in 15 per cent hot water for 6 min followed by 0.08 per cent pectinase treatment for $60 \mathrm{~min}$ at $50^{\circ} \mathrm{C}$. This extract was used for syrup development.

\subsection{Development and storage of flower extract beverage}

On the basis of FSSAI specification, the syrup was prepared by mixing different combinations of flower extract and sugar syrup as given in Table 1. Citric acid was added in different concentration to attain the desirable $(1.50 \%)$ acidity, whereas, for preservation $600 \mathrm{ppm}$ sodium benzoate was added. The best treatment combination syrup was selected on the basis of sensory evaluation, and packed in pre-sterilized glass and PET bottles (transparent bottles of $700 \mathrm{ml}$ capacity) and properly labeled. The product was stored for six months at ambient $\left(20-25^{\circ} \mathrm{C}\right)$ as well as refrigerated temperature $\left(4-7^{\circ} \mathrm{C}\right)$ conditions. The physicochemical and sensory characteristics of all the products were estimated at zero, three and six months of storage.

Table 1: Treatment detail of different combinations of Rhododendron syrup

\begin{tabular}{|l|l|l|l|l|l|l|l|l|}
\hline Treatment & $\mathbf{T}_{1}$ & $\mathbf{T}_{2}$ & $\mathbf{T}_{3}$ & $\mathbf{T}_{4}$ & $\mathbf{T}_{5}$ & $\mathbf{T}_{\mathbf{6}}$ & $\mathbf{T}_{7}$ & $\mathbf{T}_{\mathbf{8}}$ \\
\hline $\begin{array}{l}\text { Flower } \\
\text { extract (\%) }\end{array}$ & 25 & 30 & 35 & 40 & 25 & 30 & 35 & 40 \\
\hline TSS $\left({ }^{\mathbf{0}} \mathbf{B}\right)$ & 65 & 65 & 65 & 65 & 70 & 70 & 70 & 70 \\
\hline
\end{tabular}

\subsection{Physicochemical analysis}

For measurement of visual colour of beverage, Lovibond Colour Tintometer Model PFX-1 spectrophotometer was used. Colour units RYBN including CIE readings was considered and expressed as TCU (tintometer colour units). Estimation of various parameters such as, total soluble solids (TSS) in ${ }^{\circ} \mathrm{B}$ (degree brix), sugars (\%), titratble acidity $(\%)$, ascorbic acid $(\mathrm{mg} / 100 \mathrm{~g})$ and anthocyanin content (mg/100 g) was carried out as per method described by Ranganna (2009). Total phenols were determined by methods given by Singleton and Rossi (1965) with the use of Folin Ciocalteu as redox reagent. For determination of antioxidant activity the method was followed from Brand-Williams et al. (1965).

\subsection{Sensory evaluation}

Sensory parameters such as colour, body, taste, aroma and overall acceptability of the product was done by using nine point hedonic rating test (Amerine et al., 1965). Evaluation of organoleptic parameters was done by selecting panel of ten to twelve panelists.
Sensory panel comprised of faculty and students of department of Food Science and Technology, Dr. YSP UHF, Nauni, Solan (HP). The evaluation was done at ambient conditions.

\subsection{Statistical analysis}

The data on physicochemical characteristics were analyzed by using completely randomized design (CRD) before and during storage by preparing one way and three way ANOVA table. Whereas, randomized block design was used for the analysis of sensory data of rhododendron syrup in accordance with Mahony (1985). The experiments on recipe standardization and storage studies were replicated three times and five times, respectively.

\section{Results}

3.1 Standardization of recipe for the preparation of rhododendron flowers syrup

The data pertaining to physicochemical and sensory characteristics of rhododendron flowers syrup prepared by following different recipes are presented in Table 2 and 3, respectively.

\subsubsection{Physicochemical characteristics}

Table 2 indicates the physicochemical data of different recipes of rhododendron flower syrup. The colour of syrup of different recipes as visual red ranged from 18.13 to 20.98 , whereas, colour as yellow TCU ranged from 1.87 to 2.41 . Treatment, $\mathrm{T}_{8}$ was recorded with maximum red TCU value as 20.98 , whereas lowest value was recorded in $\mathrm{T}_{1}$ (18.13). From yellow TCU, treatment $\mathrm{T}_{1}$ was recorded with maximum value (2.41) which was statistically at par with $\mathrm{T}_{5}$, whereas, lowest (1.87) was found in $\mathrm{T}_{8}$ which was statistically at par with $\mathrm{T}_{4}$. TSS of first four recipes were maintained $65^{\circ} \mathrm{B}$ and rest at $70^{\circ} \mathrm{B}$ and titratable acidity as 1.50 per cent in all the recipes during the product preparation. The range of total sugars and reducing sugars from all recipes was recorded as 62.81 to 67.79 and 46.88 to 52.58 per cent, respectively. Highest total sugars $(67.79 \%)$ were recorded in recipe $\mathrm{T}_{8}$ and lowest $(62.81 \%)$ in recipe $\mathrm{T}_{1}$. The maximum $(52.58 \%)$ reducing sugars were recorded in $\mathrm{T}_{8}$ and minimum $(46.88 \%)$ in $\mathrm{T}_{1}$. The ascorbic acid content of rhododendron syrup varied from 5.20 to $9.42 \mathrm{mg} / 100 \mathrm{ml}$ and highest $(9.42 \mathrm{mg} / 100 \mathrm{ml})$ was recorded in $\mathrm{T}_{4}$ which was statistically at par with $\mathrm{T}_{8}$ and lowest $(5.20 \mathrm{mg} / 100 \mathrm{ml})$ in $T_{1}$ which was statistically at par with $T_{5}$.

The anthocyanins contents of different recipes of syrup ranged between 18.75 to $30.62 \mathrm{mg} / 100 \mathrm{ml}$. The highest anthocyanins (30.62 $\mathrm{mg} / 100 \mathrm{ml}$ ) were recorded in $\mathrm{T}_{8}$ which was statistically at par with $\mathrm{T}_{4}$ and lowest $(18.75 \mathrm{mg} / 100 \mathrm{ml})$ in $\mathrm{T}_{1}$ which was statistically at par with $\mathrm{T}_{5}$. The total phenols content of different recipes of syrup ranged between 26.35 to $41.67 \mathrm{mg} / 100 \mathrm{ml}$ and highest $(41.67 \mathrm{mg}$ / $100 \mathrm{ml}$ ) was recorded in recipe $\mathrm{T}_{8}$ which was statistically at par with $\mathrm{T}_{4}$ and lowest $(26.35 \mathrm{mg} / 100 \mathrm{ml})$ in $\mathrm{T}_{1}$ which was which was statistically at par with $\mathrm{T}_{5}$. The antioxidant activity of all recipes was recorded in the range between 18.10 to 29.82 per cent, highest (29.82 \%) was recorded in $\mathrm{T}_{8}$ and lowest (18.10\%) in $\mathrm{T}_{1}$ which was significantly at par with $\mathrm{T}_{5}$ 
Table 2: Physicochemical characteristics of different recipes of rhododendron flowers syrup

\begin{tabular}{|c|c|c|c|c|c|c|c|c|c|c|}
\hline \multirow[t]{2}{*}{ Treatments } & \multicolumn{2}{|c|}{ Colour (TCU) } & \multirow[t]{2}{*}{$\operatorname{TSS}\left({ }^{\circ} \mathrm{B}\right)$} & \multirow{2}{*}{\begin{tabular}{|l} 
Titratable \\
acidity (\%)
\end{tabular}} & \multicolumn{2}{|l|}{ Sugars (\%) } & \multirow{2}{*}{$\begin{array}{l}\text { Ascorbic acid } \\
(\mathrm{mg} / 100 \mathrm{ml})\end{array}$} & \multirow{2}{*}{$\begin{array}{l}\text { Anthocyanins } \\
(\mathrm{mg} / 100 \mathrm{ml})\end{array}$} & \multirow{2}{*}{$\begin{array}{l}\text { Total phenols } \\
(\mathrm{mg} / 100 \mathrm{ml})\end{array}$} & \multirow{2}{*}{$\begin{array}{l}\text { Antioxidant } \\
\text { activity (\%) }\end{array}$} \\
\hline & $\mathrm{R}$ & $\mathrm{Y}$ & & & Total sugars & Reducing sugars & & & & \\
\hline $\mathrm{T}_{1}$ & 18.13 & 2.41 & 65 & 1.50 & 62.81 & 46.88 & 5.20 & 18.75 & 26.35 & 18.10 \\
\hline $\mathrm{T}_{2}$ & 18.98 & 2.20 & 65 & 1.50 & 62.95 & 47.96 & 6.71 & 22.57 & 31.45 & 22.00 \\
\hline $\mathrm{T}_{3}$ & 19.21 & 2.05 & 65 & 1.50 & 63.15 & 48.31 & 8.12 & 26.54 & 35.55 & 25.90 \\
\hline $\mathrm{T}_{4}$ & 19.75 & 1.90 & 65 & 1.50 & 63.31 & 48.82 & 9.42 & 30.60 & 41.65 & 29.80 \\
\hline $\mathrm{T}_{5}$ & 18.87 & 2.39 & 70 & 1.50 & 67.34 & 51.84 & 5.22 & 18.76 & 26.37 & 18.12 \\
\hline $\mathrm{T}_{6}$ & 19.56 & 2.18 & 70 & 1.50 & 67.49 & 52.06 & 6.73 & 21.98 & 31.48 & 22.01 \\
\hline $\mathrm{T}_{7}$ & 20.07 & 2.00 & 70 & 1.50 & 67.60 & 52.31 & 8.14 & 26.55 & 34.56 & 25.93 \\
\hline $\mathrm{T}_{8}$ & 20.98 & 1.87 & 70 & 1.50 & 67.79 & 52.58 & 9.34 & 30.62 & 41.67 & 29.82 \\
\hline $\mathrm{CD}_{0.05}$ & 0.25 & 0.10 & - & - & 0.08 & 0.17 & 0.23 & 0.22 & 0.20 & 0.38 \\
\hline
\end{tabular}

$\mathrm{T}_{1}:\left(25 \%\right.$ Juice $+65{ }^{\circ} \mathrm{B}$ TSS $) ; \mathrm{T}_{2}:\left(30 \%\right.$ Juice $+65{ }^{\circ} \mathrm{B}$ TSS $) ; \mathrm{T}_{3}:\left(35 \%\right.$ Juice $+65{ }^{\circ} \mathrm{B}$ TSS $) ; \mathrm{T}_{4}:\left(40 \%\right.$ Juice $+65{ }^{\circ} \mathrm{B}$ TSS $) ; \mathrm{T}_{5}:\left(25 \%\right.$ Juice $+70{ }^{\circ} \mathrm{B}$ TSS $) ;$ $\mathrm{T}_{6}$ : $\left(30 \%\right.$ Juice $+70{ }^{\circ} \mathrm{B}$ TSS $) ; \mathrm{T}_{7}:\left(35 \%\right.$ Juice $+70{ }^{\circ} \mathrm{B}$ TSS $) ; \mathrm{T}_{8}:\left(40 \%\right.$ Juice $+70{ }^{\circ} \mathrm{B}$ TSS $)$. R Visual red TCU; Y Visual yellow TCU; CD: Critical Difference.

\subsubsection{Sensory characteristics}

Data on sensory characteristics of different recipes of rhododendron beverage given in Table 3, indicate that the mean colour score was obtained highest (8.10) in $\mathrm{T}_{3}$ and the lowest (7.77) in $\mathrm{T}_{1}$ which was statistically at par with $\mathrm{T}_{2}, \mathrm{~T}_{5}$ and $\mathrm{T}_{6}$. The recipe $\mathrm{T}_{3}$ obtained maximum (8.20) body score which was highest among all the recipes and minimum (7.77) in $\mathrm{T}_{1}$ closely followed by $\mathrm{T}_{5}$ and $\mathrm{T}_{6}$. The highest score (8.40) of taste was awarded to recipe $\mathrm{T}_{3}$ while $\mathrm{T}_{1}$ got the lowest score (8.00) closely followed by $\mathrm{T}_{2}, \mathrm{~T}_{5}$ and $\mathrm{T}_{6}$. The maximum (7.40) score for aroma was recorded in recipe $\mathrm{T}_{3}$ and minimum (7.32) in $T_{1}$ which was closely followed by $T_{4}$ and $T_{5}$. The highest score (8.00) of overall acceptability was recorded in $\mathrm{T}_{3}$ and lowest (7.11) in $\mathrm{T}_{5}$ closely followed by $\mathrm{T}_{1}$.

Table 3: Sensory characteristics (scores) of different recipes of rhododendron syrup

\begin{tabular}{|c|c|c|c|c|c|}
\hline Treatment & Colour & Body & Taste & Aroma & Overall acceptability \\
\hline $\mathrm{T}_{1}$ & 7.77 & 7.77 & 8.00 & 7.32 & 7.13 \\
$\mathrm{~T}_{2}$ & 7.80 & 7.90 & 8.07 & 7.35 & 7.77 \\
$\mathbf{T}_{3}$ & $\mathbf{8 . 1 0}$ & $\mathbf{8 . 2 0}$ & $\mathbf{8 . 4 0}$ & $\mathbf{7 . 4 0}$ & $\mathbf{8 . 0 0}$ \\
$\mathrm{T}_{4}$ & 8.00 & 8.10 & 8.20 & 7.33 & 7.75 \\
$\mathrm{~T}_{5}$ & 7.81 & 7.79 & 8.01 & 7.34 & 7.11 \\
$\mathrm{~T}_{6}$ & 7.83 & 7.85 & 8.11 & 7.35 & 7.75 \\
$\mathrm{~T}_{7}$ & 7.91 & 7.95 & 8.20 & 7.36 & 7.85 \\
$\mathrm{~T}_{8}$ & 7.98 & 7.90 & 8.20 & 7.37 & 7.72 \\
$\mathrm{CD}_{0.05}$ & 0.07 & 0.07 & 0.14 & 0.02 & 0.13 \\
\hline
\end{tabular}

Data appended in Table 3 clearly depicted that blend of extractacid-syrup had effect on sensory characteristics of beverage. The higher colour, body, taste and aroma scores of the treatment $\mathrm{T}_{3}$ were due to best combination of extract-syrup and acid blend in this recipe. The higher overall acceptability scores of recipe $T_{3}$ might be due to better combination of extract-acid-sugar blend coupled with attractive colour and body of the product. On the basis of sensory evaluation and physicochemical characteristics, out of eight treatments, $\mathrm{T}_{3}$ was selected with 35 per cent rhododendron flower extract, $65^{\circ} \mathrm{B}$ TSS and 1.50 per cent acid content.

\subsection{Storage of rhododendron flower syrup}

\subsubsection{Physicochemical characteristics}

The data in Figure 1a and $1 \mathrm{~b}$ highlight the effect of storage period and packaging material on visual red and yellow TCU of rhododendron syrup. During storage, the red and yellow TCU decreased significantly from 19.21 to 15.41 and 2.05 to 1.54 , respectively. In comparison with ambient storage condition, the decrease was significantly lower in refrigerated storage condition. Glass bottle showed higher retention of red TCU (17.11) and yellow TCU (1.84) in comparison with PET bottles. Figure 1c depicts the effect of storage period and packaging material on TSS of the product. There was increase in TSS of syrup from 65.00 to $65.65^{\circ} \mathrm{B}$, irrespective of packaging materials and storage conditions. Interaction of the product with packaging material was found to be non-significant. Figure 1d showed the effect of storage on titartable acidity of the beverage which followed a decreasing trend. The value was decreased from 1.50 to 1.37 per cent during storage of six months, which was more under ambient conditions as compared to refrigerated conditions.

Figure 1e and $1 \mathrm{f}$ highlight the effect of storage conditions and packaging material on sugar content (reducing sugars and total sugars) of syrup. There was a general increasing trend of reducing sugars, whereas, a minute increase in total sugars in the syrup during storage, which was comparatively higher in ambient storage than refrigerated storage conditions. Reducing sugars with higher value $(50.36 \%)$ was found in PET bottle packed beverage as compared to glass packed (49.81\%) flower syrup. During storage of six months the increasing trend was from 48.31 to 53.00 per cent. However, in case of total sugars very minute increase was noticed in the range between 63.15 per cent to 64.18 per cent only.

Data appended in Figure 2a showed the effect of storage as well as packaging on ascorbic acid content of rhododendron flower extract beverage with a decreasing trend from 8.12 to $3.81 \mathrm{mg} / 100 \mathrm{~g}$. Rhododendron syrup packed in PET bottles showed lesser $(5.42$ $\mathrm{mg} / 100 \mathrm{~g}$ ) as compared to glass bottle with higher value as $5.54 \mathrm{mg} /$ $100 \mathrm{~g}$ of ascorbic acid content. The coloring pigment, anthocyanin content also showed a decreasing pattern during storage from 26.54 to $20.40 \mathrm{mg} / 100 \mathrm{ml}$ (Table 4 and Figure 2b). The syrup stored under refrigerated storage condition retained more $(24.22 \mathrm{mg} / 100$ $\mathrm{ml})$ as compared to ambient $(21.85 \mathrm{mg} / 100 \mathrm{ml})$. 


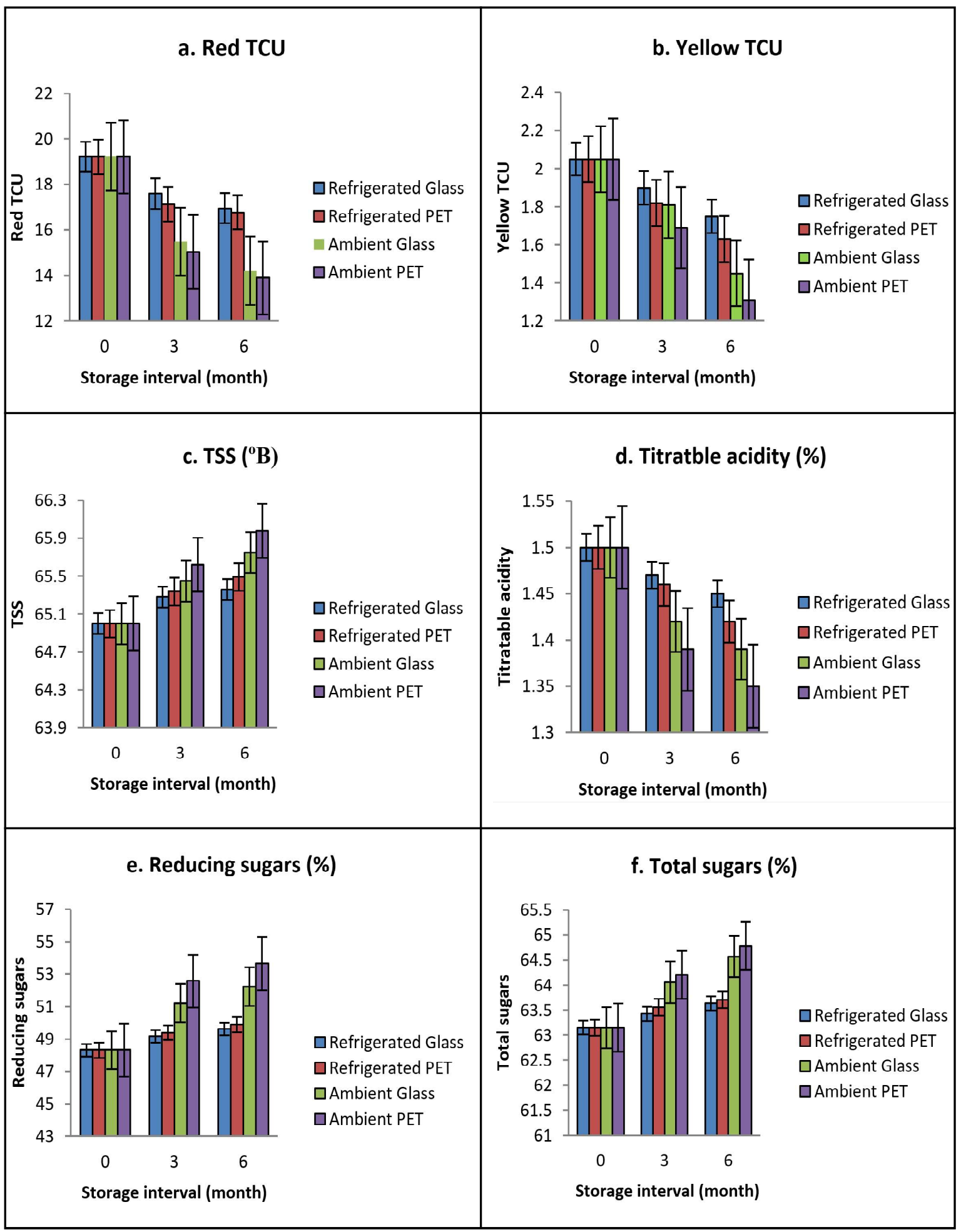

Figure 1: Effect of storage on physicochemical characteristics of Rhododendron syrup (error bars indicates standard error of the mean values). 
Table 4: Effect of packaging on ascorbic acid $(\mathrm{mg} / 100 \mathrm{ml})$ of rhododendron syrup during storage

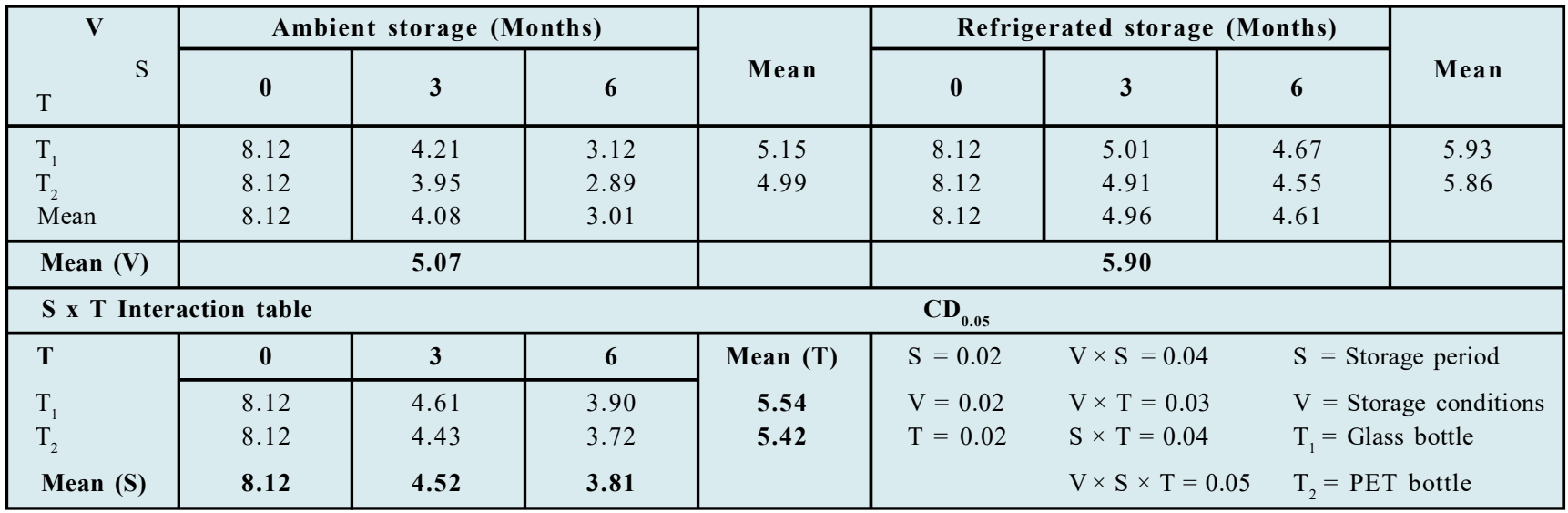

Table 5: Effect of packaging on anthocyanins $(\mathrm{mg} / 100 \mathrm{ml})$ of rhododendron syrup during storage

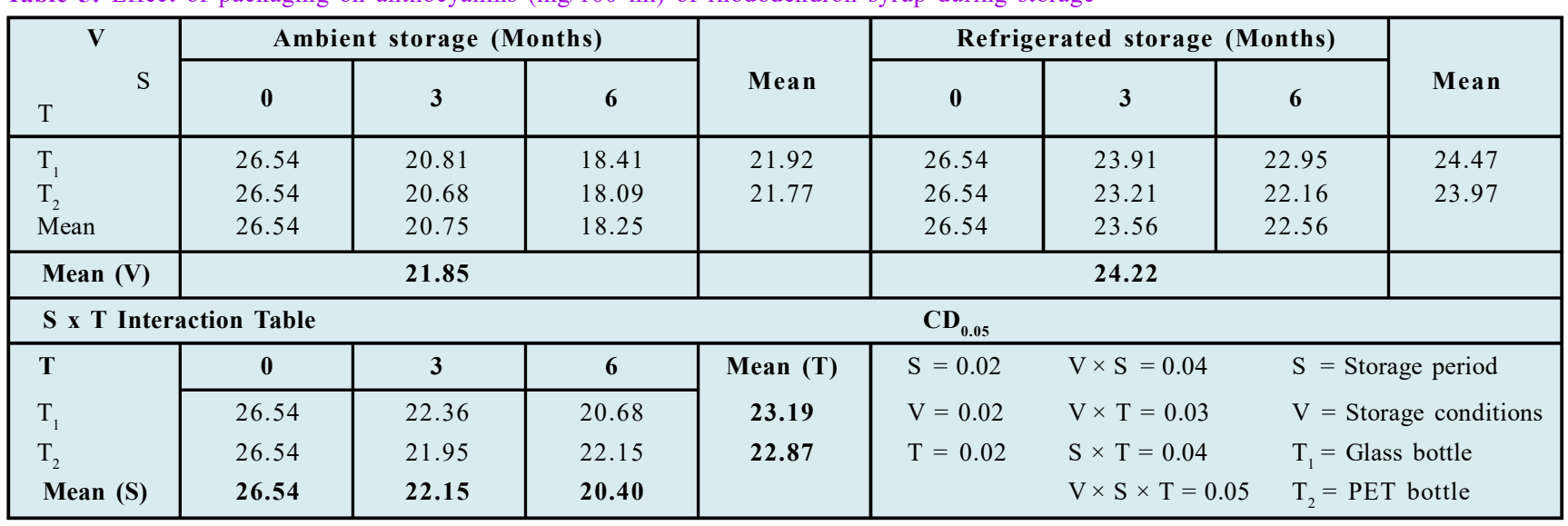

Table 6: Effect of packaging on total phenols $(\mathrm{mg} / 100 \mathrm{ml})$ of rhododendron syrup during storage

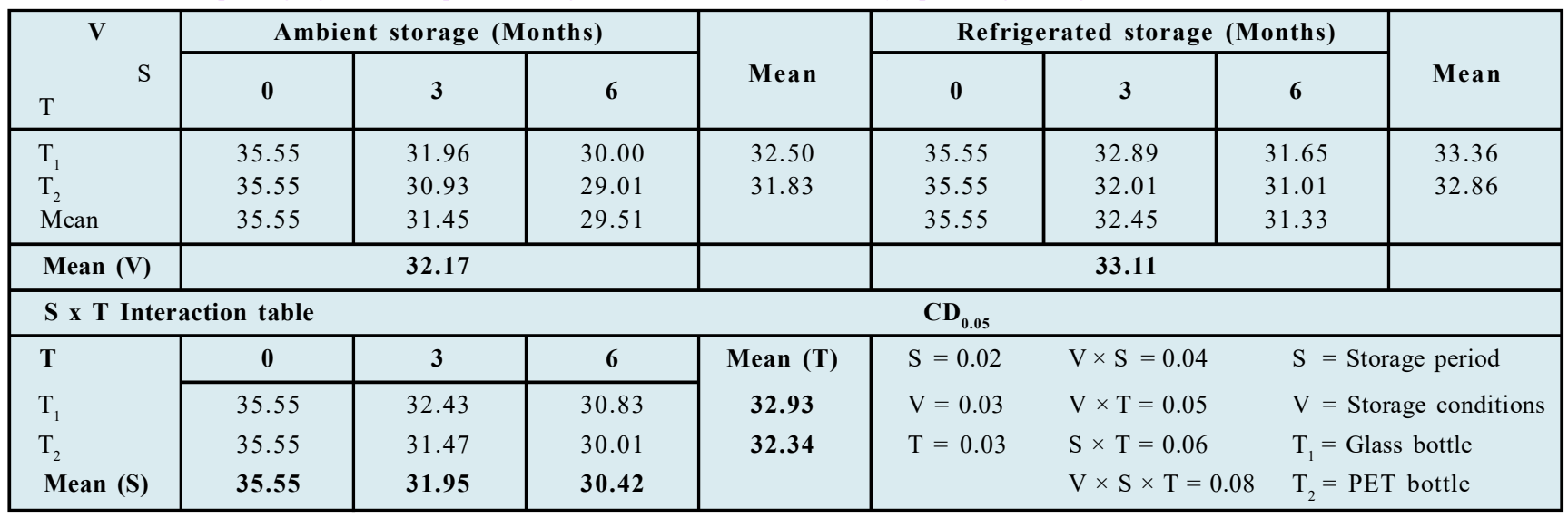

Data filled in Table 5 and Figure 2c showed total phenol content in decreasing trend from 35.33 to $30.42 \mathrm{mg} / 100 \mathrm{ml}$. The results showed better phenol retention in refrigerated conditions $(33.11 \mathrm{mg} / 100$ $\mathrm{ml})$ and in glass bottles $(32.93 \mathrm{mg} / 100 \mathrm{~g})$ in comparisons with ambient condition and PET as packaging material.
Figure $2 \mathrm{~d}$ and Table 6 indicate a gradual decrease in antioxidant activity of syrup. The higher percentage of antioxidants was found to be retained in glass packed syrup $(23.40 \%)$ and lesser in PET bottles packed extract (23.34\%). 


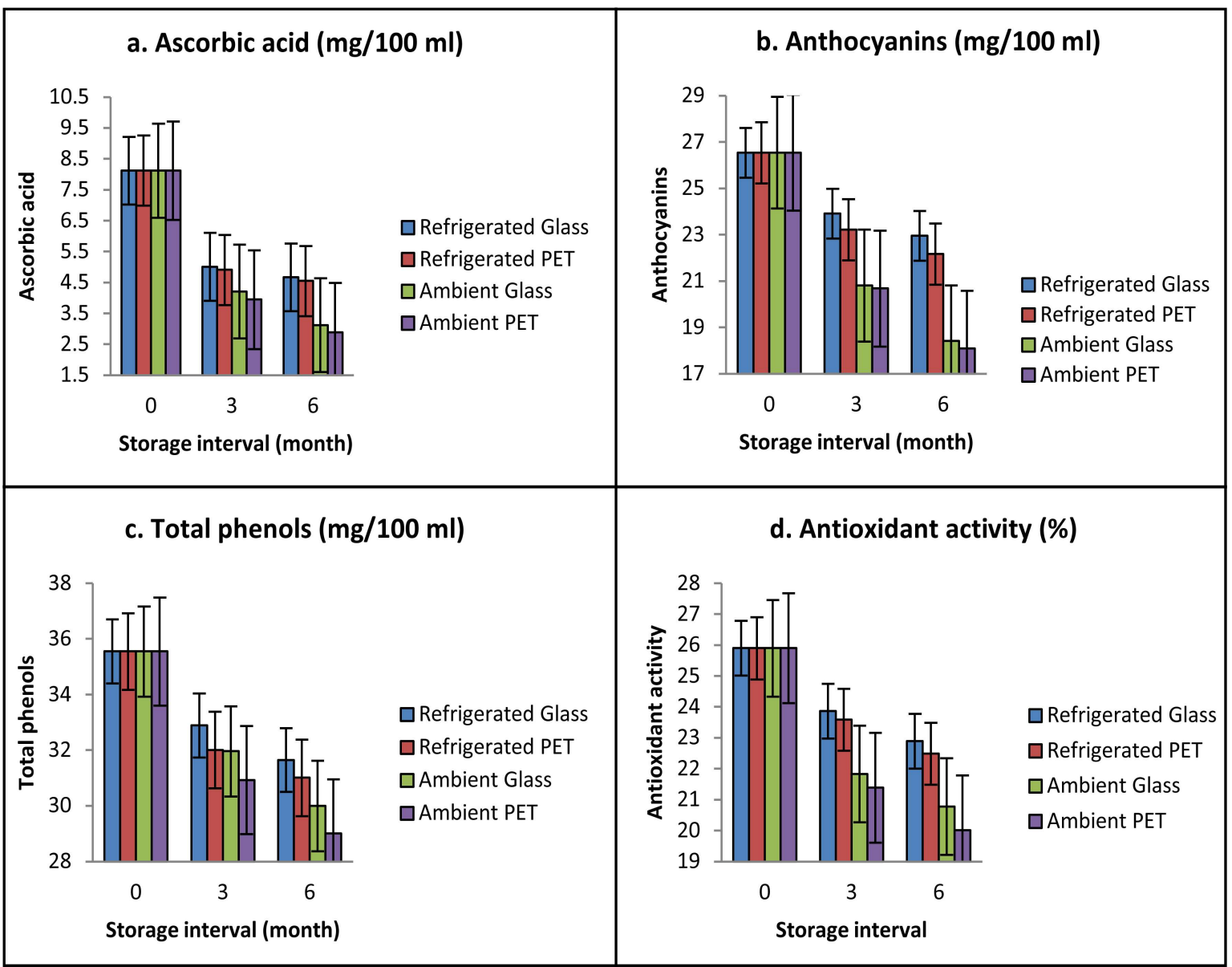

Figure 2: Effect of storage on physicochemical characteristics of rhododendron syrup (error bars indicates standard error of the mean values).

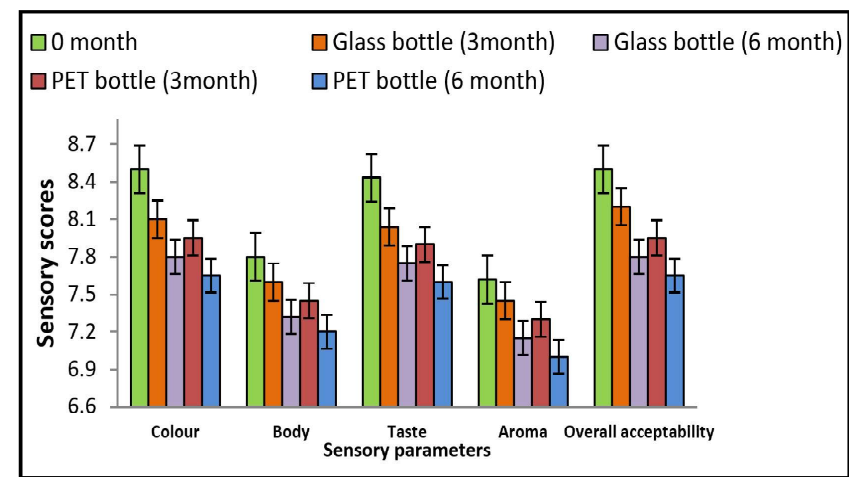

Figure 3: Effect of storage and packaging material on sensory characteristics of rhododendron syrup stored under ambient conditions (error bars indicates standard error of the mean values).

\subsubsection{Sensory characteristics of Rhododendron syrup during} storage

The sensory scores of syrup stored under ambient conditions decreased significantly during six month of storage (Figure 3 ). The scores of colour was decreased from 8.10 to 7.65 , body scores from 8.20 to 7.55 , taste score from 8.40 to 7.60 , aroma scores from 7.40

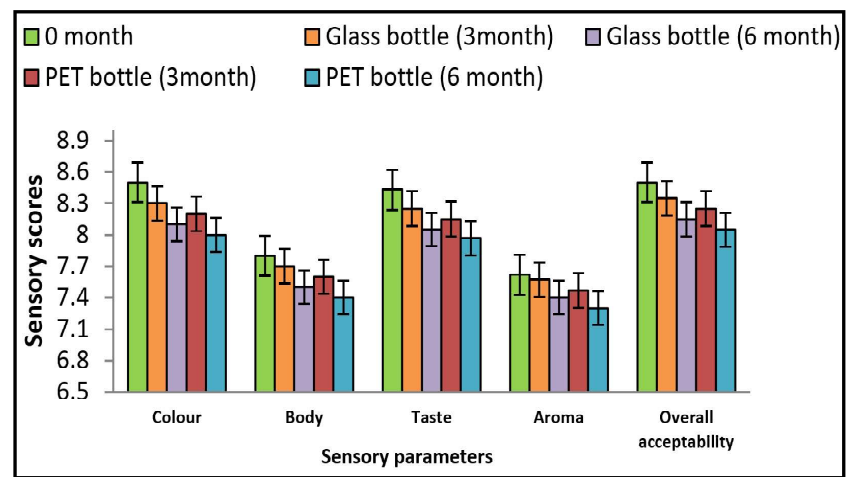

Figure 4: Effect of storage and packaging on sensory characteristics of rhododendron syrup stored under refrigerated condition (error bars indicates standard error of the mean values).

to 6.98 and overall acceptability scores from 8.00 to 6.98 . Out of two packaging material, overall sensory scores for flower extract beverage packed in glass bottles were found best as compared to PET packed flower syrup. Sensory scores for refrigerated stored flower syrup were found to be better than ambient stored product (Figure 4). The scores of colour was decreased from 8.10 to 7.75 , 
body scores from 8.20 to 7.85 , taste score from 8.40 to 8.05 , aroma scores from 7.40 to 7.13 and overall acceptability scores from 8.00 to 7.13. Although, the overall effect of storage conditions and packaging material was found to be non-significant.

\section{Discussion}

Data appended in Figure 1a and $1 \mathrm{~b}$ showed decrease in red TCU and yellow TCU value during storage of product. The reason behind this might be due to the degradation of colour component, i.e., anthocyanins present in flower extract. In case of packaging material used, less decrease was observed in glass bottle as compared to PET bottles. The reason for this might be due to slower rate of chemical reaction in the product packed in glass bottles as a result of difference in their thermal conductance properties. The results are in consistent with the work on wild prickly pear syrup (Chauhan et al., 2018), pomegranate extract (Suryawanshi et al., 2008) and mulberry syrup (Hamid et al., 2017). Acids present in the product, followed a decreasing trend which might be due to co-polymerization and reaction of organic acids with sugars and amino acids (Selvamuthukumaran and Khanum, 2013; Bhatt et al., 2020).

Figure 1c showed the effect of storage on total soluble solids present in the product. The TSS was increased in rhododendron flower extract beverage. During storage the polysaccharides present in product go through hydrolysis, which leads to the production of monosaccharides and soluble saccharides (Gould, 1983). This might be the reason for increase in total soluble solid content of the beverage during storage. Also, the reaction rate at high temperature becomes fast which increases the TSS at ambient storage conditions. The results are in conformity with pomegranate extract (Suryawanshi et al., 2008) and box myrtle beverage (Thakur and Thakur, 2017). In figure $1 \mathrm{e}$ and $\mathrm{f}$, increasing trend sugars were there during storage. This might be due to the conversion of starch into simple sugars as well as conversion of non-reducing sugars to reducing sugars. Similar results are in confirmation with wild pomegranate syrup (Thakur et al., 2018a) and in jamun syrup (Das, 2009).

Decrease in ascorbic acid content might be due to its degradation into dehydro-ascorbic acid or furfural during storage (Figure 2a). Less decrease of ascorbic acid in refrigerated storage might be due to the slower rate of its degradation in low temperature as compared to ambient conditions. The beverage packed in glass bottle retained higher amount of ascorbic acid. Due to thermal conduction properties, glasses absorb heat at slower rate as compared to PET material and retain volatile or heat sensitive compounds easily. The findings of the present studies are in agreement with the results reported in jamun fruit beverage (Das, 2009), wild pomegranate aril beverage (Thakur et al., 2013) and in box myrtle syrup (Thakur and Thakur, 2017).

Figure $2 \mathrm{~b}$ represented the loss of anthocyanin content in syrup might be due to their susceptibility to auto-oxidative degradation during storage. The anthocyanin content decreased during storage might be due to slower chemical reactions in glass bottle than PET bottles. These finding corroborates from jamun syrup (Khudiya and Roy, 1984) and wild pomegranate beverage (Thakur et al., 2018a). The decreasing trend of phenols was noticed during storage
(Figure 2c) which might be due to formation of polymeric compounds. With time these compound form complexes with proteins and form precipitates (Abers and Wrolstad, 1979). The difference in thermal conductance properties which affects the internal decomposition reactions, the phenols retention in glass was higher than flower extract beverage stored in PET bottles. Similar trends of decrease in phenols content have been reported in jamun syrup (Bhatt et al., 2020), in wild pomegranate syrup (with arils) (Thakur et al., 2018a), in wild aonla syrup (Thakur et al., 2018b), in mulberry syrup (Hamid et al., 2017) and in box myrtle syrup (Thakur and Thakur, 2017). Significant decrease in antioxidant activity during storage might be due to the degradation of anthocyanins and ascorbic acid during storage in roselle-mango blended extract (Mgaya-Kilima et al., 2015). The losses occur in antioxidant activity of the product is due to slower rate of reaction in refrigerated conditions as compared to ambient. In case of packaging material, the glass material absorb lesser heat at slower rate than PET and does not affect the antioxidant properties of the stored product. Nearly, a similar observation were recorded in thermally treated orange extract (Elez-Martinez et al., 2006) and in roselle-mango blends (Mgaya-Kilima et al., 2015).

Figures 3 and 4 depicted a decreasing trend in colour scores during storage. The reason might be that during storage due to co-polymerization of organic acids of the product change in the rate of browning reaction within the product occur and this might be the reason for lower scores given by judges. Decrease in colour scores have also been reported in rhododendron beverages (Thakur et al., 2020) and in kokum syrup (Jadhav et al., 2006). The possible reason for decrease in body scores was the formation of precipitates in the product as a result of interactions between phenols and proteins during storage. Decrease in body scores have also been reported in wild pomegranate syrup (with arils) (Thakur et al., 2013), in wild aonla syrup (Thakur et al., 2018b) and mulberry syrup (Hamid et al., 2017). The possible reason of decrease in taste scores might be due to the loss of sugar-acidextract blend responsible for taste during storage. A study conducted by Sharma et al. (2002) on plum syrup also obtains taste scores in similar pattern. The degradation of aromatic compounds in the product might led to decreased aroma scores (Thakur et al., 2020). The loss in sensory parameters might leads to decrease in overall acceptability score of the product. The findings of these studies are in agreement with the investigations reported in jamun syrup (Khurdiya and Roy, 1984), in aonla syrup (Choudhary et al., 2012).

\section{Conclusion}

From the present study, out of different combinations of flower extract and TSS tried, beverage prepared with 35 per cent extract, $65^{\circ} \mathrm{B}$ TSS and 1.50 per cent acidity was found best on the basis of sensory and some physicochemical characteristics of the product. This beverage could be stored safely for a period of six months under ambient and refrigerated storage conditions and also in both the packaging materials (glass and PET bottles). However, minimum 
changes were observed in the syrup packed in glass bottle and stored under refrigerated temperature conditions as compared to other packaging material.

\section{Acknowledgements}

Authors sincerely acknowledge Dr. Yashwant Singh Parmar University of Horticulture and Forestry, Nauni, Soaln-173230, Himachal Pradesh, India for providing entire facilities and support for conducting this research.

\section{Conflict of interest}

The authors declare that there are no conflicts of interest in the course of conducting the research. All the authors had final decision regarding the manuscript and decision to submit the findings for publication.

\section{References}

Abers, J.E. and Wrolstad, R.E. (1979). Causative factors of colour determination in strawberry preserves during processing and storage. Journal of Food Science and Technology, 44:7-5.

Amerine, M.A.; Pangborn, R.M. and Roessler, E.B. (1965). Principles of sensory evaluation of food. Academic Press, London, pp:236-268.

Bhatt, K.; Thakur, N.S.; Hamid,; Thakur, A. and Sharma, C. (2020). Optimization of juice and total soluble solids concentration for the preparation of wild jamun syrup: Effect of packaging materials and temperature conditions on nutritional quality during storage. Current Journal of Applied Science and Technology, 39:116-124.

Brand-Williams, W.; Cuvelier, M.E. and Berset, C. (1995). Use of free radical method to evaluate antioxidant activity. Lebensmittel Wissenschaft. Food Science and Technology, 28:25-30.

Chauhan, M.; Thakur, N.S.; Sharma, R.; Thakur, A. and Hamid (2018). Studies on development and storage quality of syrup prepared from wild prickly pear fruit. Journal of Hill Agriculture, 9:345-351.

Choudhary, M.L.; Verma, I.M.; Singh, J. and Godara, S.L. (2012). Studies on biochemical changes in aonla (Emblica officinalis Gaertn.) syrup under storage condition. The Horticulture Journal, 25:7-11.

Das, J.N. (2009). Studies on storage stability of jamun beverage. Indian Journal of Horticulture, 66:508-510.

Devi, S. and Vats C.K. (2017). Physicochemical characteristics of Rhododendron flowers available in different regions of Himachal Pradesh. International Journal of Agriculture Innovations and Research, 6:590-593.

Devi, S.; Vats, C.K. and Dhaliwal, Y.S. (2018). Quality evaluation of Rhododendron arboreum flowers of different regions of Himachal Pradesh for standardization of juice extraction technique. International Journal of Advances in Agricultural Science and Technology, 5:51-57.

Elez-Martinez, P.; Soliva-Fortuny, R.C. and Martin-Belloso, O. (2006). Comparative study on shelf life of orange juice processed by high intensity pulsed electric fields or heat treatment. European Food Research and Technology, 222:3-21.

Gautam, V.; Sharma, A.; Arora, S and Bhardwaj, R. (2016). Bioactive compounds in the different extracts of flowers of Rhododendron arboreum Sm. Journal of Chemical and Pharmaceutical Research, 8:439-444.
Gould, W.A. (1983). Tomato production, processing and quality evaluation ( $2^{\text {nd }}$ Edition). Avi Publication Cooporation Inc., West port, CJ.

Hamid,; Thakur, N.S.; Kumar, P. and Thakur, A. (2017). Development of syrup from mulberry (Morus alba L.) and its quality evaluation under ambient and refrigerated storage conditions. International Journal of Bio-resource and Stress Management, 8:116-121.

Heywood, N.H.; Brummitt, R.K.; Culham, A. and Seberg, G. (2007). Flowering plant families of the world. The Brown Reference Group, London. pp:422.

Jadhav, S.B.; Joshi, G.D. and Garande, V. K. (2006). Studies on preparation and storage of raw and ripe kokum (Garcinia indica Choisy) fruit products. Journal of Asian Horticulture, 2:205-207.

Kashyap, P. Anand, S. and Thakur, A. (2017). Evaluation of antioxidant and antimicrobial activity of rhododendron arboreum flowers Extract. International Journal of Food and Fermentation Technology, 7:123-128.

Katoch, R.C. (2014). Phytosociety and regenration studies of Rhododendron companulatum D. M.Sc Thesis. Dr. Y. S. Parmar University of Horticulture and Forestry, Nauni, Solan, (HP), pp:70p.

Khurdiya, D.S. and Roy, S.K. (1984). Studies on stability of anthocyanins during storage. Indian Food Packer, 28:5-8.

Krishna, H.; Attri, B.L. and Kumar, A. (2012). Improvised rhododendron squash: Processing effects on antioxidant composition and organoleptic attributes. Journal Food Science and Technology, 51:3404-3410.

Kumar, V.; Suri, S.; Prasad, R.; Gat, Y.; Sangma, C.; Jakhu, H. and Sharma, M. (2019). Bioactive compounds, health benefits and utilization of Rhododendron: A comprehensive review. Agriculture and Food Security, 8:2-7.

Mahony, M.O. (1985). Sensory evaluation of food: Statistical methods and procedures. Marcel Dekker: New York, pp:168-169.

Mgaya-Kilima, B.; Remberg, S.F.; Chove, B.E. and Wicklund, T. (2015). Physiochemical and antioxidant properties of roselle-mango juice blends: Effects of packaging material, storage temperature and time. Food Science and Nutrition, 3:100-109.

Orwa, C.; Mutua, A.; Kindt, R.; Jamnadass, R. and Simons, A. (2009). Agroforestree database: A tree reference and selection guide version 4.0 available at (http://www.worldagroforestry.org/af/treedb/)

Purohit, C.S. (2014). Rhododendron arboreum Sm.: An economically important tree of Sikkim. Popular Kheti, 2:193-198.

Ranganna, S. (2009). Handbook of analysis and quality control for fruit and vegetable products. Tata McGraw Hill Co. Ltd., New Delhi. pp: $1112 \mathrm{p}$.

Selvamuthukumaran, M. and Khanum, F. (2013). Development of spiced seabuckthorn [Elaeagnus hamnoides (L.) A. Nelson syn. Hippophae rhamnoides L.] mixed fruit squash. Indian Journal of Traditional Knowledge, 13:132-141.

Sharma, R.; Barwal, V.S. and Kaushal, B.B.L. (2002). Preparation and evaluation of spiced plum squash. Beverage and Food World, 29:23-24.

Singleton, V.L. and Rossi, J.A. (1965). Colorimetry of total phenolics with phosphomolybdic phosphotungstic acid reagent. American Journal of Enology and Viticulture, 16:144-158.

Solanki, S.N.; Huria, A.K. and Chopra, C.S. (2013). Physicochemical characterstics of buransh (Rhododendron arboreum $\mathrm{Sm}$ ), a nutritious and edible flower. Journal of Hill Agriculture, 4:50-52. 
Srivastava, P. (2012). Rhododendron arboreum: An overview. Journal of Applied Pharmaceutical Science, 2:158-162.

Suryawanshi, A.B.; Kirad, K.S.; Phad, G.N. and Patil, S.B. (2008). Effect of various levels of pasteurization, preservative and their combination on organoleptic evaluation on pomegranate juice stored at room temperature. The Asian Journal of Horticulture, 3:429-432.

Thakur, A. and Thakur, N.S. (2017). Development of syrup from box myrtle (Myrica nagi) and its quality evaluation during storage. International Journal of Agriculture Sciences, 9:3862-3865.

Thakur, N.S.; Aarti; Hamid; Thakur, A. and Gautam, S. (2020). Utilization of edible rhododendron (Rhododendron arboreum $\mathrm{Sm}$.) flowers for development of spiced beverage (appetizer) and its shelf life evaluation during storage. International Research Journal of Pure and Applied Chemistry, 21:52-62.
Thakur, N.S.; Dhaygude, G.S. and Joshi, V.K. (2013). Development of wild pomegranate aril-in syrup and its quality evaluation during storage. International Journal of Food and Fermentation Technology, 3:33-40.

Thakur, N.S.; Dhaygude, G.S.; Hamid,; Kumar, P. and Thakur, A. (2018a). Studies on development and storage quality evaluation of syrup prepared from wild pomegranate (Punica granatum L.) fruits. International Journal of Current Microbiology and Applied Sciences, 7:538-548.

Thakur, N.S.; Thakur, N.; Hamid. and Thakur, A. (2018b). Studies on development and storage quality evaluation of vitamin $\mathrm{C}$ rich syrup prepared from wild aonla (Phyllanthus emblica L.) fruits. The Pharma Innovation Journal, 7:167-172.

Tiwari, O.N. and Chauhan, U.K. (2006). Rhododendron conservation in Sikkim Himalaya. Current Sciences of India, 90:532-541.

Citation N.S. Thakur, Aarti, Sunakshi Gautam, Aashu Chandel, Neerja Rana, Abhimanyu Thakur and Hamid (2020). Comparative assessment of Rhododendron (Rhododendron arboreum Sm.) flowers extract beverages through biochemical analysis and its quality evaluation during storage. Ann. Phytomed., 9(2):223-231. http://dx.doi.org/ 10.21276/ap.2020.9.2.20 